\title{
Sylwia Urbańska*
}

\author{
Uniwersytet Warszawski
}

\section{CZEGO NIE DOWIEMY SIĘ O GLOBALNEJ REWOLUCJI PŁCI BEZ BADANIA RELIGII W ŻYCIU MIGRANTÓW ${ }^{1}$}

\begin{abstract}
Badania rewolucji płci w globalnych migracjach, mimo że są prowadzone w perspektywie intersekcjonalnej, sporadycznie włączają do analiz zagadnienia religii i religijności w doświadczeniu wyjeżdżających. Obszary, w których szuka się fenomenów świadczących o zmianie społecznej, to przede wszystkim zagadnienia podziału pracy oraz nowych form opieki realizowanej przez migrantów obu płci wobec dzieci lub starszych rodziców zabranych ze sobą lub pozostawionych w kraju pochodzenia. Dokonując wstępnego przeglądu wyników polskich i międzynarodowych badań prowadzonych na skrzyżowaniu problematyki migracji, płci kulturowej, pracy i opieki oraz religijności, pokazuję, że włączenie do analiz doświadczeń religijności migrantów pomogłoby pełniej odpowiedzieć na pytanie, czy wraz z migracjami mamy do czynienia z rewolucją płci. A także: jakie są jej możliwe kierunki i znaczenie dla samych mężczyzn i kobiet.
\end{abstract}

Słowa kluczowe: globalne migracje, rewolucja płci, płeć kulturowa, religia i religijność, transnarodowość

\section{WPROWADZENIE}

Od kiedy badacze mobilności dostrzegli, że oprócz mężczyzn miliony pracownic z krajów biedniejszego Południa i uboższych regionów Północy migrują samodzielnie do zamożnych metropolii Europy i USA, począwszy od lat 90. coraz częściej pojawiają się analizy związków między migracją a płcią (Morokvasic 1984; Hondagneu-Sotelo 2001; Phizacklea 2002; Kofman 2000; Mahler i Pessar 2001). A wraz z nimi pytania, które można byłoby zredukować do jednego. Czy mamy do czynienia z globalną rewolucją płci (Parrenas 2001; Hochschild i Ehrenreich 2003)? Migrujące za pracą kobiety stają się przecież nie tylko głównymi żywicielkami rodzin, ale też oddają opiekę nad swoimi dziećmi pozostałym w kraju bliskim. A także włączają się w tworzenie wielu migracyjnych organizacji. Jak zatem zmieniają się wzorce kobiecości i męskości, relacje między płciami, instytucje regulujące ich role i reżimy płci w procesach migracyjnych? Czy efekt ewentualnej zmiany widoczny jest także w krajach wysyłających, czy tylko przyjmujących migrantów?

* Adres do korespondencji: Sylwia Urbańska, Instytut Socjologii Uniwersytetu Warszawskiego, ul. Karowa 18, 00-927 Warszawa; e-mail: urbanskas@is.uw.edu.pl.

1 Artykuł powstał w ramach finansowanego przez Narodowe Centrum Nauki grantu SONATA BIS, „Płeć kulturowa jako czynnik różnicujący organizacje religijne. Płciowe praktyki społeczne i ich interpretacje w organizacjach Polskiej Misji Katolickiej w Anglii, Szwecji i Belgii”, nr 2014/14/E/HS6/00327. 
Wydawałoby się, że aby odpowiedzieć na te pytania, powyższy nurt badawczy, który uczynił z przemian wzorców i relacji płci trzon badań nad migracjami (Mahler i Pessar 2006), nie obędzie się bez analizy przekonań i doświadczeń religijnych migrantów, a także roli, jaką odgrywają organizacje religijne w ich przemianie. Przecież normy regulujące wyobrażenia i wzorce płci są w dużej mierze powiązane z normami zakorzenionymi w religijnych dogmatach (por. Kościańska 2009; Voicu 2009). A realizacji tych ostatnich pilnują rozliczne świeckie i nieświeckie organizacje, które na różne sposoby mogą mediować w zmianie. Inicjują ja, wspomagają, katalizują, ale też odrzucają, blokują niektóre jej rejony, mogą ją opóźniać, a nawet traktować z wrogością, w efekcie wzmacniając tradycyjne praktyki (por. Graff 2008; Korolczuk 2014; Radzik 2014, 2015). Jakiekolwiek zatem pytania o to, czy pod naporem masowej wędrówki pracownic - ale też innych typów migrantów - konserwatywne wzorce tożsamości i ról społecznych przekształcą się, w jakim kierunku i z jakim znaczeniem dla migrantek oraz migrantów, nie powinny omijać zagadnień związanych z szeroko rozumianą sferą religii. Niestety, bardzo trudno jest znaleźć analizy, które włączałyby religijność jako jeden $\mathrm{z}$ równoprawnych wymiarów badania rewolucji płci w migracjach.

A już wstępna lektura nielicznych publikacji skupionych na relacjach między migracjami - religią - płcią pokazuje interesujące wyniki. Przywołując tylko wyrywkowe przykłady, widzimy, co jeszcze, poza czynnikami ekonomicznymi, wpływa na umacnianie się globalnych rynków pracy opiekuńczej. Na przykład Vivianne Jackson pokazuje, w jaki sposób odpowiedzialność za drugiego człowieka - związana z przekonaniami religijnymi filipińskich migrantek w Izraelu - opóźnia decyzję o rezygnacji z pracy opiekunki i pomocy domowej osób starszych (2013). Przekonania religijne bywają zatem istotną przyczyną wyjazdu lub powrotu migrantów do kraju, a na pewno znacząco mediują w procesie podejmowania decyzji. Podobnie obszar badania imigranckich religijnych zgromadzeń oraz powiązanych z nimi prywatnych i publicznych świeckich instytucji pokazuje, jak organizacje i ich reguły, ale też wierzenia były zmieniane przez migrujące kobiety i mężczyzn, ich kolejne pokolenia. Ciekawym przykładem są badania kobiet ze społeczności kwakrów, które choć były matkami i żonami, począwszy od XVII wieku wyjeżdżały samotnie na wieloletnie wyprawy misyjne do innych krajów. Kobiety te z sukcesem przetransformowały zarówno instytucję macierzyństwa i małżeństwa, jak i swoje społeczności. Udało im się zrewolucjonizować upłciowione relacje i uprawomocnić transnarodowe macierzyństwo (Calkings 2005). Bez analizy komponentu religijnego nie moglibyśmy w pełni zrozumieć, jak było to możliwe. Jego włączenie umożliwia pogłębione badanie przemian wzorców upodmiotawiania, przesunięć na drabinie statusu społecznego, przemian kontraktu płci, a także przekształceń samej religijności. Pozwala lepiej zrozumieć, co wpływa na kierunek przemian w procesach migrowania. Dlaczego czasami kończą się one reakcją zwrotną (backlashem), a w innych sytuacjach większą inkluzyjnością i egalitaryzmem nowych układów płci. Jak wpływają na kraje pochodzenia. Badań takich wciąż jednak jest za mało (Levitt 2008).

Celem opracowania jest zatem wstępny przegląd tego typu badań. Artykuł składa się z dwóch części. W pierwszej pokazuję, wokół jakich tematów ogniskują się badania płci w migracjach. Spróbuję wyjaśnić, dlaczego do tego typu analiz nie jest włączany wymiar religijny. W drugiej części przechodzę do omówienia wyników analiz krzyżujących perspektywy badania migracji, płci oraz religijności, które naświetlają nowe wymiary rewolucji płci w migracjach. 
Czego nie dowiemy się o globalnej rewolucji płci bez badania religii w życiu migrantów

\section{POSTSEKULARNY SCEPTYCYZM}

Od wielu dekad zauważa się słabnącą pozycję religii w badaniach ponowoczesnych społeczeństw (Levitt 2008). Niewielkie zainteresowanie religią w badaniu migracji do krajów zamożnej Północy wyjaśniane jest sceptycyzmem współczesnych badaczy z obszaru nauk społecznych co do znaczenia religii w życiu jednostki w postsekularnej Europie i Ameryce Północnej (Ebaugh i Chafetz 2000). Taki niedostatek opracowań jest symptomatyczny, bo paradoksalnie, wielu badaczy zbiera dane właśnie w obrębie organizacji religijnych, gdzie można spotkać migrantów. Są to zwykle kościoły, misje i stowarzyszenia religijne, które w kraju pobytu pełnią funkcję formalnych i nieformalnych sieci pomocy społecznej (por. Małek 2008). Instytucje te działają w innym kontekście społeczno-kulturowym, więc dostosowują się do potrzeb migrantów, nierzadko za sprawą ich samych, co sprawia, że różnią się od swoich lokalnych odpowiedników w kraju. Z takich miejsc i sieci korzysta wielu migrantów ekonomicznych, nie tylko osoby związane z daną religią. Spora część badaczy i badaczek analizujących migracje spędziło mnóstwo czasu w tego typu misjach i zgromadzeniach (np. Grzymała-Kazłowska 2001; Kordasiewicz 2008; Patzer 2010; Kuźma 2013; Urbańska 2015; Koralewska 2016; omówienie starszych badań zob. Małek 2008). Takie miejsca umożliwiały prowadzenie obserwacji w społecznościach migrantów, ułatwiały spotkania i nawiązywanie kontaktów, a także same w sobie były kontekstem obserwowania przemian relacji społecznych. Jednak nieliczne z tych badań systematycznie włączają sferę religii i religijności do analiz (Małek 2009; Koralewska 2016), mimo że w feministycznych badaniach migracji podkreśla się wagę intersekcjonalnej perspektywy (Lutz i Pallenga-Mollenbeck 2012), a więc zwracania uwagi na istotność różnorodnych identyfikacji i pozycji w układach społecznych. $\mathrm{Z}$ podobnym stanem rzeczy spotykamy się przy badaniu migracji z innych krajów.

\section{DOMINACJA PERSPEKTYWY EKONOMICZNEJ}

Badania przemian wzorców i relacji płci w migracjach w dużej mierze polegają na analizie procesów ekonomicznych i globalnych nierówności, analizie globalnych rynków pracy migrantek, sposobów rekonstrukcji pracy opiekuńczej oraz układów płci w migracjach. Warto omówić podstawowe wątki tego popularnego od dwóch dekad nurtu badań, by znaleźć punkty, które umożliwiłyby włączenie wymiaru płeć-religia.

Fundamentalne pytanie o to, czy rewolucja płci zachodzi w globalnych procesach migracyjnych, łączy się z dostrzeżeniem zjawiska feminizacji migracji (Sassen 2007), będącego skutkiem pogłębiania się ekonomicznych różnic centrum-peryferie (Wallerstein 1992). Od końca lat 70. XX wieku zwraca się uwagę na kilka gigantycznych globalnych strumieni migrantek kierujących się z biednego Południa czy Europy Środkowo-Wschodniej ku krajom bogatej Północy. Dzieje się to w związku z rosnącymi nierównościami społeczno-ekonomicznymi, ubóstwem krajów peryferyjnych na skutek rosnącego zadłużenia, kryzysem opieki w bogatszych krajach Północy i neoliberalizacją polityk, spychających opiekę i edukację ku procesom komercjalizacji. Ważne staje się odkrycie zmieniającego się charakteru kobiecych migracji. Zaczęto dostrzegać, że kobiety stają się autonomicznymi aktorami migracji. 
Nie wyjeżdżają na zaproszenie mężczyzn, którzy wyemigrowali wcześniej, by przygotować środki do życia i dom na emigracji. Wyjeżdżają masowo jako pionierki migracyjne, na czas pracy zostawiając w kraju rodziny, mężów, partnerów i dzieci. Zauważano też, że kobiety już dawniej podróżowały samodzielnie, były autonomicznymi aktorkami migracji (Morokvasic 1984). Nowe badania pojawiły się jako krytyka „ślepych na płeć kulturową” badań migracyjnych głównego nurtu (Kontos i Liapi 2010: 7-8).

Centralnym tematem analiz staje się kwestia nowych podziałów opieki i pracy domowej, związanej z masową migracją pomocy domowych, opiekunek i pielęgniarek do pracy w relatywnie zamożniejszych gospodarstwach domowych krajów Północy. Tutaj mówi się o dwóch wektorach zmiany społecznej. Choć podkreśla się emancypacyjne doświadczenia upodmiotowienia kobiet, zyskania bezpieczeństwa ekonomicznego i/lub socjalnego, jak i wzrost wartości rynkowej pracy domowej, z drugiej strony mówi się o reakcji zwrotnej i zatrzymanej rewolucji (backlash, stalled revolution, por. Hochschild i Machung 1989). Zwraca się uwagę, że mężczyźni nie przejmują obowiązków domowych ani w gospodarstwach, które eksportują migracyjne pracownice, ani w tych, które je zatrudniają. Mamy za to do czynienia z masowym outsourcingiem pomocy domowych, które teraz pochodzą nie tylko z innej narodowości, ale też grupy etnicznej, religijnej, rasowej czy klasowej (Parrenas 2001). Mówi się nawet o powrocie służących, nazywanych globalnymi proletariuszkami oraz o powrocie rozszerzonych gospodarstw domowych z nowymi hierarchiami pracownic (McDowell 2007). Współczesne migrantki stają się mieszkankami gorszych dzielnic. A także bohaterkami segregacji zawodowej w ramach wtórnego, nierzadko nielegalnego, zorientowanego na tańsze, mało prestiżowe prace rynku usług, gdzie reprodukowane są etniczne, płciowe i rasowe nierówności (Slany, Kontos i Liapi 2010). Badania te skupiają się zatem na pokazywaniu odmiennych strukturalnych przyczyn migrowania kobiet - ujawnianiu poszczególnych warstw ,sieci dominacji”.

Choć perspektywa ekonomiczna praktycznie zdominowała analizy, coraz częściej zwraca się uwagę na fakt, że oprócz przyczyn ekonomicznych, takich jak ubóstwo i bezrobocie, wyjazdy bywają też strategią radzenia sobie z dyskryminacją na rodzimym rynku pracy (Pustułka 2015), poszukiwania innych wzorców życia (Piotrowski, Kaźmierska i Waniek 2011). Badacze zwracają uwagę na to, że kobiety uciekają od przemocowych i opresyjnych rodzinnych lub małżeńskich relacji (Dreby 2010; Urbańska 2015), a sama migracja jest postrzegana jako czynnik emancypujący, otwierający przestrzeń większych możliwości (Anthias i Lazardis 2000; Kofman et al. 2000; Anthias i Cederberg 2010, zob. „postmodernizacja ubogich”, Urbańska 2015). Ciekawe, zwłaszcza w kontekście badań nad religijnością, są analizy treści kilkudziesięciu powieści napisanych przez migrujące po 2004 roku Polki. Główną przyczyną wyjazdu bohaterek literackich jest w tym przypadku ucieczka od konserwatyzmu rodzin, zamkniętych horyzontów społeczności, łączonych z polską specyfiką religii katolickiej (Kronenberg 2015). Badaczki płci i migracji same zresztą coraz częściej podkreślają, że należy wyjść poza redukowanie przyczyn migracji do czynników ekonomicznych lub poszerzać je o czynniki społeczno-kulturowe, polityczne, bo grozi to przesłonięciem istotnych powodów wyjazdów oraz zjawisk związanych ze zmianą społeczną wokół migracji.

Badaczki podsumowujące stan wiedzy w ramach obszaru migracje i płeć podkreślają, że „mimo bogatej literatury na temat migrujących kobiet, badania migracji są nadal oparte na 
stereotypach płci, co sprawia, że migrantki są ciągle postrzegane przez role reprodukcyjne, co ma dalekie konsekwencje dla ich społecznych reprezentacji (Kontos i Liapi 2010: 12). Dlatego w ostatnich latach widać coraz większe zainteresowanie badaczy udziałem migrantów i migrantek w procesach zbiorowych: reprodukcji granic narodowych i etnicznych; doświadczeń integracji i zakorzeniania; udziału w ruchach społecznych i organizacjach na rzecz praw pracowniczych, czy przedsiębiorczości skupionej wokół nisz etnicznych; ale też transnarodowych formalnych i nieformalnych sieci migracyjnych (Anthias i Cederberg 2010). Procesy te zachodzace na poziomie organizacyjnym i zbiorowym bada się jako element i wypadkową, ,upłciowionych reżimów migracyjnych”. Na te ostatnie składają się ramy instytucjonalne w państwach wysyłających oraz przyjmujących migrantów, które definiują zarówno to, kto czerpie korzyści z migracji oraz regulują przepływy osób, idei i praktyk (Kofman et al. 2000).

Formułuje się też postulat, żeby „,zwracać uwagę, w jaki sposób płeć krzyżuje się z innymi społecznymi wymiarami, takimi jak etniczność, rasa, klasa, dzięki czemu uniknęłoby się ryzyka homogenizacji doświadczeń kobiet (Anthias i Cederberg 2010: 28)". Badania religii i religijności, o których się nie wspomina przy wyliczaniu wymiarów intersekcjonalności, mogłyby odsłonić nierozpoznane wymiary sprawczości, która rodzi się, gdy krzyżują się różne tożsamości, statusy i pozycje społeczne. Wiele badań wskazuje na bezpośrednie związki między religijnymi wartościami a sprawczością i przekonaniami. Zwraca się uwagę na to, że patriarchalne postawy wobec ról płciowych są mocno skorelowane z tradycją chrześcijańską. Oparcie tej tradycji na zmaskulinizowanej kulturze wpłynęło na uprawomocnienie różnic w relacjach między mężczyznami a kobietami, czego wyrazem jest utożsamianie roli kobiet z opiekuńczością i sferą domu niż miejscem na rynku pracy (Voicu 2009: 145, za: Sherkat 2000; Hofstede 1980, 1991). Migracja jako ważny mechanizm modernizacyjny sprzyja sekularyzacji (Voicu 2009), stąd włączenie wymiaru religijnego do badania rewolucji płci jest konieczne, by w ogóle móc uchwycić zmianę. Tym bardziej, że jak pokazuje Linda Woodhead, religijność może być nie tylko mechanizmem reprodukującym zastany porządek władzy, w tym relacji płci, ale też źródłem siły, sprawczości, by taki zastany porządek zmieniać na różne sposoby od środka lub z pozycji zewnętrznych (2013). Dla wielu osób źródłem sprawczości i upodmiotowienia, często jedynym, jest duchowość i praktyki religijne. Agnieszka Kościańska tłumaczy, że starsze pokolenia Polek, które w największym stopniu stały się ofiarami wykluczających mechanizmów transformacji, właśnie w religijności i wspólnotowych praktykach z nią związanych znalazły jedyne źródło sprawczości (Kościańska 2009). A zatem włączenie wymiarów religijności do analizy jest niezbędne, by uniknąć ryzyka homogenizacji, kolonizacji, „orientalizacji” doświadczeń migrantek, które, jak pokazuje Kościańska, są obecne w dominujących nurtach feminizmu liberalnego.

\section{RELIGIA I WZORCE PŁCI W BADANIACH MIGRACJI}

Warto przyjrzeć się, jakie miejsce w badaniach migracji z perspektywy płci kulturowej przypada zjawiskom związanym z religią i religijnością. Trzeba jednak zaznaczyć, że syntetyczne omówienie tego zagadnienia nie jest proste $\mathrm{z}$ dwóch przyczyn. 
Po pierwsze, szersze zainteresowanie problematyką religii w relacji do procesów migracyjnych zaczęło być widoczne dopiero od lat 90 . XX wieku i na początku rozwijało się powoli (Cadge i Ecklund 2007). Popularność zyskuje dopiero w ostatnich latach, co wynika z intensyfikacji migracji i fenomenów z tym związanych. Jeśli w 2000 roku liczbę migrantów na świecie szacowano na 175 mln osób kierujących się ku krajom Północy, to już w 2013 roku zauważono wzrost liczby migrantów aż o 33\%, co w przeliczeniu wynosi o 57 mln więcej migrantów w porównaniu z poprzednią dekadą. W ten sposób w 2013 roku szacowano ogół migrantów już na 232 osób. W samej Europie było już wtedy 104 mln migrantów, co stanowi ogromny skok w porównaniu z 72 mln szacowanych dekadę wcześniej (International Migration Report UN 2013). Rosnąca w geometrycznym tempie skala migracji, w tym migracji uchodźczych, ale też szereg pytań o kwestie integracji migrantów, polityki multikulturalizmu, wykluczenie, wojny i konflikty społeczne, paniki moralne oraz kwestie związane z międzynarodowym terroryzmem sprawiają, że głosów za włączeniem religii do badań migracyjnych pojawia się coraz więcej.

Po drugie, syntetyczne omówienie wyników badań rozbija się o ograniczenia metodologiczne zastanych analiz. Są to przede wszystkim prace monograficzne, opisowe, dokumentujące działalność instytucji. Głównie skupione na analizach małych, etnicznych zgromadzeń religijnych imigrantów. Wśród nich mało jest badań porównawczych, syntezujących zgromadzoną wiedzę. Na przykład w Stanach Zjednoczonych, które od początku istnienia są państwem imigracyjnym i wieloreligijnym - bo co czwarty mieszkaniec to imigrant w pierwszym lub drugim pokoleniu - ważniejsze prace pojawiają się dopiero od lat 90. Są to przede wszystkim monografie pojedynczych organizacji religijnych - lokalnych zgromadzeń i kongregacji tworzonych przez imigrantów, z pierwszej i kolejnych generacji. Analizy te nie wychodzą jednak poza opis, brakuje w nich uogólnień teoretycznych i zestawień porównawczych, a zagadnienia płci pojawiają się tam jedynie przy okazji (Cadge i Ecklund 2007). Podobnie dzieje się w kontekście polskim. Choć mamy bogatą tradycję badań rodzimych parafii i misji, która rozciaga się na cały XX wiek, zgromadzony dorobek tworzy dwa podstawowe nurty badań. Do pierwszego należy socjologiczna analiza roli instytucji religijnych i duszpasterstwa w krajach napływu. Rozliczne prace, począwszy od Chłopa polskiego w Europie i Ameryce (Thomas i Znaniecki 1976), analizują religijne i świeckie funkcje polskich parafii imigracyjnych. Wskazuje się ich rolę w budowaniu związków między religijnością a etnicznością, funkcję więziotwórczą, wsparcie w procesie adaptacji, asymilacji, a także rozliczne funkcje praktyczne związane z szukaniem pracy, mieszkania, pomocy w codziennych sprawach (por. Małek 2008). Drugi nurt to badania dokumentujące działalność tych instytucji, prowadzone między innymi przez Instytut Badań nad Polonią i Duszpasterstwem Polonijnym KUL. Jednak, jak zauważa Agnieszka Małek: „W polskiej literaturze przedmiotu została bogato udokumentowana działalność parafii i skupisk polonijnych, bazująca na materiałach zastanych: dokumentach archiwalnych, księgach parafialnych, artykułach prasowych. Nieliczne są natomiast prace ukazujące znaczenie etnicznych ośrodków religijnych dla samych migrantów, które bazowałyby na bezpośrednich relacjach" (2008: 283). A takich, które uwzględniają perspektywę płci kulturowej, można przywołać niewiele. Na przykład pionierskie badania Agnieszki Małek, która przyjrzała się religijnym doświadczeniom imigrantek z Polski w Rzymie, sposobom ich angażowania się w działalność polonijnych parafii i praktyki transnarodowe (2008). 
Interesujące są również najnowsze analizy prowadzone przez Ingę Koralewską, która w latach 2012-2015 rozmawiała z polskimi migrantkami w Islandii. Opierając się na wywiadach $\mathrm{z}$ migrantkami próbowała odpowiedzieć na pytanie, czy towarzyszący migracji proces emancypacji religijnej, rozumianej jako proces indywidualizacji religijnej, wiąże się ze zmianą postrzegania roli kobiety w społeczeństwie (zob. w niniejszym numerze s. 19-33).

Dopiero niedawno pojawiły się pierwsze analizy podsumowujące empiryczny dorobek badawczy z pogranicza religii, migracji i płci (Levitt i Jaworsky 2007). Opierając się właśnie na tych syntezach uzupełnionych o analizy monografii z ostatnich lat, spróbuję wyłonić kilka cieszących się szczególnym zainteresowaniem tematów. Należą do nich: przemiany strukturalne instytucji świeckich i religijnych, świeckie i religijne tożsamości w migracjach, upłciowione religijne różnice między kolejnymi pokoleniami migrantów. Choć nie są to obszary rozłączne, każdy z nich omówię oddzielnie.

\section{PRZEMIANY STRUKTURALNE INSTYTUCJI ŚWIECKICH I RELIGIJNYCH}

Jednym z kluczowych obszarów są analizy strukturalnych przemian organizacji religijnych w relacji do analogicznych w krajach pochodzenia. Tutaj zwraca się uwagę na odmienny udział kobiet i mężczyzn jako inicjatorów zmiany. Jest on efektem innej pozycji migrantów na upłciowionym rynku pracy oraz przyjmowania odmiennych wzorców działania. W nowych warunkach otwierają się przestrzenie dla upodmiotowienia, ale też retradycjonalizacji.

Podstawowym wymiarem badania przemian organizacyjnych jest próba zrozumienia, w jak różnorodny sposób instytucje te mediują w procesie integracji imigrantów do życia w nowym kraju. Większość monografii dokumentuje ogromną rolę organizacji religijnych w świadczeniu formalnej i nieformalnej pomocy społecznej imigrantom. Szersza niż w krajach pochodzenia funkcja niereligijna parafii i misji obejmuje cały zakres nieformalnego wsparcia, między innymi pomoc w znalezieniu mieszkania, pracy, szkoły i opieki dla dzieci, a nawet zakładaniu własnej działalności gospodarczej i braniu kredytów hipotecznych. Takie działania podejmują nie tyle duchowni, ile osoby świeckie skupione wokół instytucji, w dużej mierze kobiety. Wiele kongregacji pomaga szczególnie intensywnie w pierwszym okresie adaptacji w nowym kraju. Na przykład buddyjskie zgromadzenia w nowojorskim Chinatown oferują świeżo upieczonym imigrantom nie tylko schronienie, ale i żywność (Guest 2003). Szereg analiz pokazuje, że organizacje i zrzeszenia religijne dla migrantów w Europie pełnią podobne funkcje. Warto wspomnieć o roli Polskich Misji Katolickich we wspieraniu migrantów ekonomicznych z Polski, z której to pomocy korzystają również osoby identyfikujące się z inną religią lub niewierzący. Polskie misje oferują nieformalnie przestrzeń, w której migranci z Polski mogą wymieniać się różnego rodzaju pomocą i kontaktami (czasami migranci robią to odpłatnie, co jest przyczyną wielu frustracji), a świeccy wolontariusze wspierać w trudnych sytuacjach życiowych, takich jak thumaczenie przy porodzie, wsparcie w razie wypadku (przykładowo złamania nogi w trakcie nielegalnej pracy na budowie), poinformowanie rodziny w Polsce o śmierci krewnego i zebranie funduszy na transport zwłok do kraju, opiekę psychologiczną (telefony zaufania), terapie dla Anonimowych Alkoholików, nie wspominając już o udostępnianiu przestrzeni do edukacji dzieci w ojczystym języku (Grzymała-Kazłowska 2001; Kordasiewicz 2008; Małek 2008; Kuźma 2013; Urbańska 2015). 
Czasami rozbieżności w definiowaniu funkcji są tak duże między organizacjami religijnymi w krajach pochodzenia i w krajach wysyłających migrantów, że część z organizacji znacząco poluzowuje więzi z centralami. Nierzadko też dochodzi do rozłamów. Gertrud Hüwelmeier, która z historycznej perspektywy opisuje utransnarodowienie życia w konwentach (2013), zwraca uwagę, w jaki sposób pozaeuropejskie filie zakonów żeńskich stopniowo uniezależniały się na przełomie XIX i XX wieku od swoich centrali i od samych matek przełożonych. Zmianę uprawomocniły reformy z lat 60. ubiegłego wieku, po II Soborze Watykańskim, które miały wspierać funkcje misyjne zakonów. Opisując amerykańskie filie pierwszych pokoleń zakonnic migrujących do USA z konwentu Poor Handmaids of Jesus Christ w Niemczech, Hüwelmeier pokazuje, że symbolem walki o zniesienie hierarchii, nową idę̨ siostrzeństwa i niezależność stała się kwestia noszenia ubrań cywilnych zamiast habitu oraz posiadania własnej hierarchii. Imigrantki walczyły o partnerskie relacje z centralą i matką przełożoną w Niemczech (2012). Antropolożka zwraca jednak uwage, że ten proces indywidualizacji dotyczył przede wszystkim pozaeuropejskich filii zakonów. Wysyłane tam zakonnice stopniowo się indywidualizowały, a dołączające z tubylczych społeczności Afryki, Azji, Ameryki Południowej, z czasem domagały się uwzględnienia ich kulturowych odmienności. Hüwelmeier opisuje protesty rdzennych Hindusek, które walczyły z etnocentrycznymi praktykami swoich matek przełożonych. Pragnęły wprowadzić lokalne wzorce kulturowe, rytuał siedzenia zamiast klęczenia, spożywania posiłków bliskich kuchni hinduskiej zamiast niemieckiej (2013).

Niejednokrotnie nowe praktyki zmieniały centrum. Na przykład w USA hierarchiczne u podstaw kościoły imigrantów mają z czasem tendencję do przekształcania się w małe zgromadzenia, stowarzyszenia, w których panują bezpośrednie, horyzontalne relacje. Jest to efekt wpływu amerykańskiej kultury opartej na kongregacjonalizmie (Warner i Witter 1998; Yang i Ebaugh 2001). I choć wiele $\mathrm{z}$ tych zgromadzeń nadal jest prowadzonych przez zawodowych duchownych, z roku na rok coraz bardziej centralne miejsca zajmują w nich laiccy liderzy i liderki. Dotyczy to zwłaszcza młodych organizacji. W nowym kontekście zmieniają się też rytuały, praktyki i style modlitwy (Yang i Ebaugh 2001). Takie zmiany przenoszone są potem przez migrantów do krajów pochodzenia. Badania migrantek z Ameryki Południowej w USA pokazują, że odgrywają one dużą rolę w eksportowaniu idei kongregacjonalizmu do miejsc, $\mathrm{z}$ których wyjechały. Takie zmiany nie zawsze dotyczą samych struktur i praktyk organizacji religijnych, ale też świeckich instytucji, które są z nimi blisko powiązane. Dotyczy to na przykład instytucji macierzyństwa i szeroko rozumianych ról płciowych. Badania Susanny Calkings, która zajmowała się społecznościami kwakrów, pozwalają odkryć, że transnarodowe matki, które zupełnie zrewolucjonizowały instytucję macierzyństwa i układy płci w swoich społecznościach, były już w XVII wieku. Były to kwakierki, żony i matki, które samodzielnie i z własnej inicjatywy, wiedzione powołaniem wyjeżdżały na wieloletnie zagraniczne misje. Rewolucja, którą zapoczątkowały, była spektakularna: udało im się stworzyć coś na kształt instytucji matek zastępczych we wspólnocie, a swoją rolę kobiety matki przekształcić w prawomocną i podziwianą rolę duchowej matki wspólnoty (2005). Oczywiście nie były to masowe migracje, jak współczesne wyjazdy pracownic, żon i matek, które na wiele lat pozostawiają swoje rodziny w kraju pochodzenia. Kwakierek wyjeżdżających na misje było niewiele, a ich wyjazdy były pionierskie nawet 
w ich społecznościach. Jednak przypadki te pokazują ogromną rolę religii jako środka uprawomocnienia zmian praktyk macierzyńskich i przemian układów płci w społecznościach wysyłających. Poszukiwanie źródeł legitymizacji takiej zmiany tylko w wymiarze nowego podziału pracy opiekuńczej w migracyjnym gospodarstwie domowym - a zatem z wyłączeniem religii, jak robi się to w większości tego typu badań - nie dałoby odpowiedzi, dlaczego takie rewolucyjne przedsięwzięcia się udawały.

Niektóre badania analizują konteksty, w jakich zmienia się struktura organizacji kościelnej. Odmienne strategie są często odpowiedzią na nowe układy płci i relacje między męskością a kobiecością, które tworzą się na emigracji. Nierzadko odbierane jako zagrożenie dla starych akceptowanych układów. Antropolodzy, na przykład Gertrude Hüwelmeier badająca Wietnamczyków w Berlinie, jak i badacze zajmujący się różnymi afrykańskimi odmianami Kościoła zielonoświątkowego w Europie, zwracają uwagę na powiązanie przemian tych struktur kościelnych właśnie z nowymi, upłciowionymi doświadczeniami migrantów. Kościoły i zgromadzenia przejmują rolę negocjatorów wobec zagrożonych dotychczasowych układów płci i relacji między małżonkami. Szwajcarskie Kościoły zielonoświątkowe z Ghany i Kongo zaczynają wręcz specjalizować się w intensywnych rytuałach oczyszczeń kobiet i mężczyzn rzekomo uwiedzionych, nawiedzonych przez demony (spirit spouses, mermaids). Według interpretacji duchownych demony te psują relacje rodzinne i małżeńskie albo nie pozwalają znaleźć męża lub żony osobom samotnym. Kościoły stają się realnie centrami terapeutycznymi dla małżeństw i par toczonych kryzysem małżeńskim na emigracji. Socjologiczna analiza źródeł tych kryzysów pokazuje, że stoi za nimi trudniejsza pozycja mężczyzn na rynku pracy, która pociąga za sobą niełatwą do zaakceptowania przez nich zamianę ról w relacjach intymno-rodzinnych. Otóż mężczyznom trudniej jest znaleźć pracę na emigracji, w przeciwieństwie do kobiet, które lepiej sobie radzą, bo mają większe szanse znalezienia zatrudnienia w opiece i przy sprzątaniu. Doświadczeniem migrantów częściej zatem staje się degradacja statusu w stosunku do pozycji przed wyjazdem, a także niewidzialność. W takim kontekście kościoły, oprócz nowej terapeutycznej funkcji, przeobrażają się również w miejsca nawiązywania relacji intymnych dla samotnych par, o tyle ważne, że odtwarzające więzi etniczne. W ten sposób wspomniane rodzaje praktyk i specjalizacji kościołów, realizowanych marginalnie lub niespotykanych w afrykańskich krajach pochodzenia, staje się na emigracji medium zarządzania relacjami płci (Rey 2013). Podobnie dzieje się z buddyjskimi świątyniami badanymi przez Hüwelmeier w Berlinie (2013). Są one w dużej mierze fundowane i zakładane przez wietnamskie przedsiębiorczynie, które nierzadko lepiej sobie radzą z biznesem niż mężczyźni. Pozycja fundatorek, organizatorek i wolontariuszek na rzecz świątyń znacząco zmienia ich miejsce w strukturze religijnej w kraju migracji, w relacji do konserwatywnych struktur organizacji w Wietnamie.

Niestety, analizy relacji sieciowych łączących lokalne centra religijne z ich szerszymi makrostrukturami pojawiają się nader rzadko (Cadge i Ecklund 2007: 363). Trudno jest podsumowywać, w jakim stopniu te zmiany strukturalne są trwałe i włączane na coraz wyższe poziomy. Potrzeba pogłębionych badań porównawczych, a także badań w perspektywie transnarodowej, które uwzględnią ponadnarodowe konteksty oraz upłciowione reżimy migracyjne. 


\section{ŚWIECKIE I RELIGIJNE TOŻSAMOŚCI W MIGRACJACH}

Kolejnym istotnym wątkiem badań są sposoby, w jakie religia zapośrednicza i kształtuje indywidualne i grupowe tożsamości w migracyjnych kontekstach (Cerulo 1997). Jako że najwięcej zmian w tym obszarze identyfikowanych jest na linii tożsamości narodowych, etnicznych i płciowych, badanie tych wymiarów cieszy się szczególnym zainteresowaniem.

Wśród analiz przemian wzorców płci najwięcej dotyczy zagadnienia konstruowania płci w obrębie religijnych organizacji. Badań takich jest znacznie więcej niż tych, które mogłyby pokazać, w jaki sposób religia i płeć mediują w innych kontekstach doświadczania migracji, zwłaszcza takich, które dzieją się poza zgromadzeniami religijnymi (Cadge i Ecklund 2007: 365). Tymczasem, kiedy przyjrzymy się zmianie społecznej, której bohaterkami są migrantki, widać kilka złożonych, czasem ambiwalentnych procesów dziejących się w obrębie organizacji religijnych.

Religia bywa dla imigrantek zasobem upodmiotawiającym. Zwłaszcza w sytuacji, kiedy $\mathrm{w}$ organizacjach religijnych kraju migracyjnego stykają się z mniej patriarchalnymi strukturami niż w krajach, z których wyjechały. Może być też używana do kontestacji zastanego porządku. Na przykład Sheba Mariam George pokazuje, w jaki sposób chrześcijanki z Indii używają ram religijnych do umocnienia swojej tradycyjnej kultury. Tą strategią świadomie odcinają się od zliberalizowanego amerykańskiego chrześcijaństwa (1998). Kontestacje te nie ograniczają się wyłącznie do konserwowania tradycyjnej kultury. Ich głębszy wymiar ma na celu budowę ruchów społecznych lub mobilizację do protestów, jak dzieje się to w przypadku meksykańskiego katolicyzmu. Staje się on polityczno-moralnym zasobem wykorzystywanym przez jednostki lub świeckie i religijne organizacje do artykulacji politycznego oporu. Jego przykładem są protesty na granicy Meksyku i USA (Hondagneu-Sotelo et al. 2004). Niejednokrotnie mamy też do czynienia ze strategiami hybrydalnymi. Z jednej strony w organizacjach religijnych kobiety reprodukują tradycyjną etniczną kulturę, a jednocześnie coraz częściej obejmują w tych organizacjach wysokie i prestiżowe stanowiska, których mężczyźni nie byliby w stanie, a czasami nie chca, poprowadzić. Takie wzorce zauważyły Ebaugh i Chafetz, badając trzynaście organizacji religijnych w amerykańskim Houston. Zauważyły też, że mężczyźni aktywizują się na rzecz swoich społeczności, dopiero gdy tracą status pracownika (Ebaugh i Chafetz 1999). Natomiast Jolly i Reeves przypominają, że nawet jeśli mężczyźni działają w swoich etnicznych organizacjach, zazwyczaj wybierają takie, których polityki nakierowane są na cele w krajach pochodzenia (Hardy-Fanta 1993). Wyjaśnieniem takich strategii jest gorsza adaptacja mężczyzn do życia w krajach migracyjnych. Na przykład badania pierwszej generacji amerykańskich imigrantów z Ameryki Południowej pokazują, że dla latynoskich mężczyzn imigracja wiąże się z przymusem podejmowania prac poniżej ich kwalifikacji i deskilizacją, co jest między innymi konsekwencją związanej z rasizmem segregacji amerykańskiego rynku pracy. Rezultatem tego jest niechęć do osiedlania się i poczucie, że wyjazd ma charakter tymczasowy, nawet jeśli za granicą spędza się wiele lat. Opór przed angażowaniem się w lokalne działania jest zatem wypadkową takich doświadczeń. Natomiast doświadczenia kobiet, żon imigrantów, są zupełnie odmienne. Wraz z migracją kobiety doświadczają awansu społecznozawodowego, a więc zyskują relatywną niezależność. Wiąże się to z zyskaniem dostępu do odpłatnych w ogóle lub lepiej płatnych zajęć, nawet w sytuacji gdy są one nadal związane 
z pracą troski i sprzątaniem. Ponadto opiekuńcze role, które pełnią w swoich gospodarstwach domowych jako żony i matki, włączają je skuteczniej w życie społeczności lokalnych, zintegrowanych wokół szkół, placów zabaw, pomocy społecznej i organizacji religijnych. To wszystko przekłada się na lepszą adaptację w nowym środowisku i na niechęć do powrotu do ojczystego kraju. Nie dziwi zatem, że kobiety chętniej niż mężczyźni angażują się w działania organizacji religijnych, które rozwiązują lokalne problemy (Hardy-Fanta 1993), i znacznie częściej niż mężczyźni uzyskują obywatelstwo USA (Jones-Correa 1998).

Podobne zjawisko zauważa Mehrdad Darvishpour (2002), badająca patriarchalne rodziny irańskie w zorientowanej na egalitaryzm Szwecji. Badaczka zauważa, że to właśnie matki chcą się bardziej integrować z kulturą i społeczeństwem kraju, który stał się ich nowym domem, niż mężczyźni. Widać to na przykładzie odmiennych podejść do sposobu wychowywania córek, które są znacznie bardziej ograniczane przez ojców. Autorka podkreśla, że „w wielu rodzinach imigranckich mężczyźni żyją w przeszłości, kobiety w teraźniejszości, a dzieci w przyszłości (2002: 14). Dodaje też, że „ci, którzy w wyniku migracji zdają się tracić najwięcej ze swej pozycji społecznej i w rodzinie, najsilniej starają się kultywować jak najmniej zmienione tradycyjne relacje społeczne i rodzinne" (Muszel 2013: 92, za: Darvishpour 2002). Taka różnica podejść staje się oczywiście przedmiotem konfliktów i sporów.

Badania pokazują jeszcze inne upłciowione źródło nowych tożsamości kobiet, które znacznie mocniej angażują się w działalność etnicznych kościołów i religijnych zgromadzeń niż w krajach pochodzenia. Istotnym czynnikiem przyciagającym jest wsparcie opiekuńcze i pomoc w edukacji potomstwa, uzyskiwane w wyniku dołączenia do sieci społecznych skupionych wokół organizacji religijnych. Trudno obyć się bez nich zwłaszcza rodzinom imigrantów ekonomicznych pracujących w najniższych sektorach rynku pracy, a więc doświadczających wielokrotnego wykluczenia. Bankston i Zhou $(1995,1996)$ argumentują, że wietnamskie dzieci i ich opiekunki uzyskują w organizacjach religijnych ochronę i wsparcie, które umożliwia sukces edukacyjny, oraz lepszą adaptację w społeczeństwie amerykańskim. Badacze społeczności chińskich imigrantów z klas robotniczych w nowojorskim Chinatown pokazują, że dostęp do takiej przyjaznej przestrzeni ma znaczenie szczególnie dla nastoletnich imigrantów, którzy są podatni na „niebezpieczne i destrukcyjne wzorce zachowań”. Sieci skupione wokół tamtejszych świątyń pełnią dla nich funkcję podobną do rodzin zastępczych, w których uzyskują wsparcie społeczne, finansowe, opiekuńcze, co ułatwia proces awansu społecznego do klasy średniej (Cao 2005; Guest 2003, 2004).

Nowe tożsamości religijne powstają również jako reakcja na doświadczenie wykluczenia, niewidzialności i życia na marginesie przyjmującego kraju. Agnieszka Małek, która badała Polki pracujące jako pomoce domowe w Rzymie, zwraca uwagę, że część kobiet dopiero na emigracji staje się religijna. Doświadczenie samotności, rozłąka z rodziną, ciężka praca, nielegalność pobytu, pracy i zamieszkania, a także negatywne doświadczenia z pracodawcami, izolacja opiekunek pracujących w gospodarstwach domowych, sprawiają, że wiele kobiet szuka wyjaśnienia sensu swojego życia i pracy w religii, zaczyna się utożsamiać z postaciami świętych, takich jak Maryja lub Jezus, angażuje się w życie polskich wspólnot religijnych (2008). Można powiedzieć, że religia stanowi w procesach migracyjnych ważny symboliczny zasób dla rosnącej liczebnie klasy globalnego proletariatu, który pomaga radzić sobie z nowymi warunkami życia i formami uklasowienia. 


\section{POKOLENIA MIGRANTÓW A RELIGIA I PŁEĆ}

Interesującym obszarem badań są relacje między kolejnymi pokoleniami imigrantów, wzorcami płci i religijności a przekształceniami samych organizacji religijnych. $Z$ jednej strony zauważa się, że drugie pokolenie migrantów bywa krytyczne w stosunku do wzorców transmitowanych przez pierwsze pokolenie. Na przykład w USA redefiniowanie wzorców religijności rodziców, chrześcijan z Indii, jest związane z socjalizacją do amerykańskiego indywidualistycznego sposobu przeżywania religijności, widzianej jako proces, który konstruuje jednostka (Kurien 2004). Przejawia się to na przykład chęcią otwierania organizacji na wyznawców religii z innych grup etnicznych, działalności charytatywnej na rzecz różnorodnej społeczności spoza etnicznych diaspor i enklaw. Takie próby kończą się czasami odejściem ze struktur religijnych, „,ichym exodusem” drugiego pokolenia (Chai 2001). Nie brakuje również badań, które pokazują proces odwrotny. Zwraca się uwagę na to, że drugie albo trzecie pokolenie imigrantów, które często poszukuje swojej tożsamości i potrzebuje się określić, staje się nawet bardziej konserwatywne w stosunku do swoich rodziców z pierwszego lub drugiego pokolenia. Jednym z przykładów takich badań są analizy postaw pierwszego i drugiego pokolenia uchodźczyń z Czeczenii. Alicja Szczepanikowa podkreśla, że niezależność zdobyta dzięki emigracji przez matki nie spotyka się z aprobatą córek, które zwracają się w kierunku konserwatywnego i religijnego stylu życia, między innymi wybierając pozostanie w domu i poświęcenie się pracy opiekuńczej (Szczepanikova 2012).

\section{ZAKOŃCZENIE}

W badaniach zmiany społecznej wokół płci w procesach migracyjnych wymiar religijny pojawia się rzadko. Najczęściej jako założenie, że kobiety i mężczyźni pochodzą z konserwatywnych religijnie środowisk, kultur, z których dzięki migracji mogą się wyzwolić. Rozpoznawczy przegląd nielicznych badań, które włączają religijność, odsłaniają szereg fenomenów, dzięki którym lepiej można zrozumieć procesy migracyjne, a zwłaszcza kierunki i złożoność rewolucji płci. Widać też wyraźnie, że niejednokrotnie to zakorzeniona w religijności sprawczość i siła może być źródłem prowadzącej ku egalitaryzmowi zmiany.

Peggy Levitt, jedna z czołowych badaczek globalizacji i transnarodowych migracji, specjalizująca się równolegle w badaniu religijności, twierdzi, że bez umieszczenia religii w centrum badań nad migracjami nie będziemy w stanie zrozumieć, jak redefiniowane są tożsamości i przynależności w globalizującym się świecie (Levitt 2003). Wykorzenienie milionów ludzi i całych zbiorowości z ich kontekstów kulturowych, w tym kontekstów religijnych, i wrzucenie ich w nowe warunki, w których funkcjonują inne wzorce działania, wymusza wybór i negocjacje między różnymi alternatywnymi sposobami życia. Włączenie wymiaru religijności jest zatem konieczne nie tylko po to, by dowiedzieć się, jak kształtują się nowe normy postępowania, ale też - by poznać zjawiska stojące u podstaw pluralizacji oraz multiplikacji wiary i praktyk religijnych (Speck 2013) w czasach wzmożonej mobilności. 
Czego nie dowiemy się o globalnej rewolucji płci bez badania religii w życiu migrantów

\section{BIBLIOGRAFIA}

Anthias, Floya i Maja Cederberg. 2010. Gender, Migration and Work: Perspectives and Debates in the UK, w: Maria Kontos, Maria Liapi and Krystyna Slany (red.), Women in New Migrations. Current Debates in European Societiest, Kraków: Wydawnictwo Uniwersytetu Jagiellońskiego, s. 19-50.

Anthias, Floya i Gabriella Lazaridis. 2000. Introduction: Women on the Move in the Southern Europe, w: Floya Anthias, Gabriella Lazaridis (red.), Gender and Migration in Southern Europe - women on the move, Oxford - New York: Berg-Oxford International Publishers Ltd, s. 1-14.

Bankston, Carl L. i Min Zhou. 1995. Religious participation, ethnic identification, and adaptation of and Adaptations in Immigrant Congregations, Walnut Creek, CA: AltaMira.

Bankston, Carl L. i Min Zhou. 1996. The ethnic church, ethnic identification, and the social adjustment of Vietnamese adolescents, ,Review of Religious Research”, 38, 1: 18-37.

Boyd, Monica i Elisabeth Grieco. 2003. Women and Migration: Incorporating Gender into International Migration Theory, http://www.migrationinformation.org/Feature/print. $\mathrm{cfm} ? \mathrm{ID}=106$ [6.05.2016].

Cadge, Wendy i Elaine Howard Ecklund. 2007. Immigration and Religion, „Annual Review of Sociology”, 33, 1: 359-379.

Calkings, Susanna. 2005. „Forsaking Their Children”: Distance, Community, and Unbecoming Quaker Mothers 1650-1700, w: Diana Gustafson (red.), Unbecoming Mothers. The Social Production of Maternal Absence, New York: The Haworth Press, s. 123-140.

Cao, Nanlai. 2005. The church as a surrogate family for working class immigrant Chinese youth: an ethnography of segmented assimilation, „Sociology of Religion”, 66, 2: 183-200.

Cerulo, Karen A. 1997. Identity construction: new issues, new directions, „Annual Review of Sociology", 23, 1: 385-409.

Chai, Karen J. 2001. Beyond 'strictness'to distinctiveness: generational transition in Korean Protestant churches, w: Ho-Young Kwon, Kwang Chung Kim and R. Stephen Warner (red.), Korean Americans and their religions: Pilgrims and missionaries from a different shore, University Park, PA: Pennsylvania State University Press, s. 157-180.

Darvishpour, Merhdad. 2002. Immigrant Women Challenge the Role of Men: How the Changing Power Relationship within Iranian Families in Sweden Intensifies Family Conflicts after Migration, „Journal of Comparative Family Studies”, 33, 2: 271-296.

Ebaugh, Helen Rose i Janet S. Chafetz. 1999. Agents for Cultural Reproduction and Structural Change: The Ironic Role of Women in Immigrant Religious Institutions, „Social Forces", 78, 2: 585-612.

Ebaugh, Helen Rose i Janet S. Chafetz. 2000. Religion and the New Immigrants: Continuities and Adaptations in Immigrant Congregations. Walnut Creek: Alta Mira.

George, Sheba. 1998. Caroling with the Keralites: The Negotiation of Gendered Space in an Indian Immigrant Church, w: R. Stephen Warner and Judith Wittner (red.), Gatherings in Diaspora: Religious Communities and the New Immigration, Philadelphia: Temple University Press, s. 265-294. 
Glick Schiller, Nina. 2003. The Centrality of Ethnography in the Study of Transnational Migration: Seeing the Wetlands Instead of the Swamp, w: Nancy Foner (red.), American Arrivals: Anthropology Engages the New Immigration, Santa Fe: School of American Research Press, s. 99-128.

Glick Schiller, Nina, Linda Basch i Cristina Blanc-Szanton (red.). 1992. Towards a Transnational Perspective on Migration: Race, Class, Ethnicity, and Nationalism Reconsidered, t. 4-5, New York: New York Academy of Sciences.

Graff, Agnieszka. 2008. Rykoszetem. Rzecz o ptci, seksualności i narodzie, Warszawa: W.A.B. Grzymała-Kazłowska, Aleksandra. 2001. Polscy nielegalni pracownicy w Belgii. Raport z badań, „CMR Working Papers” 41, Warszawa: Ośrodek Badań nad Migracjami UW.

Guest, Kenneth J. 2003. God in Chinatown: Religion and Survival in New York's Evolving Immigrant Community, New York: New York University Press.

Hardy-Fanta, Carol. 1993. Latina Politics - Latino Politics, Philadelphia: Temple University Press.

Hochschild, Arlie Russell i Barbara Ehrenreich (red.). 2003. Global Woman: Nannies, Maids and Sex Workers in the New Economy, New York: Metropolitan Press.

Hochschild, Arlie Russell i Anne Machung. 1989. The second shift: working families and the revolution at home, New York: Viking.

Hondagneu-Sotelo, Pierrette. 2001. Domestica: Immigrant Workers Cleaning and Caring in the Shadows of Affluence, Berkeley: University of California Press.

Hofstede, Geert. 1980. Culture's Consequences: International Differences in Work Related Values, London: Sage.

Hofstede, Geert. 1991. Culture and Organization: Software of Mind, London: McGraw Hill.

Hüwelmeier, Gertrud. 2010. Female Believers on the Move: Gender and Religion in Vietnamese Pentecostal Networks in Germany, w: Glenda Lynna, Anne Tibe Bonifacio i Vivienne Angeles (red.), Gender, Religion and Migration: Pathways of Integration, Lanham: Lexington Books, s. 115-131.

Hüwelmeier, Gertrud. 2013. 'Our future will be in India': Traveling Nuns between Europe and South Asia, w: Ester Gallo (red.), Migration and Religion in Europe. Comparative Perspectives on South Asian Experiences, Ashgate, s. 45-57.

Hüwelmeier, Gertrud. 2012. „The Daughters have grown up”. Transnational Motherhood, Migration and Gender among Catholic Nuns, w: Karin Kröber i Ina Merkel (red.), Imagined Families in Mobile Worlds, „Ethnologia Europaea” Special Issue, 42, 2: 26-35.

Hüwelmeier, Gertrud. 2013. Bazaar Pagodas - Transnational Religion, Postsocialist Marketplaces and Vietnamese Migrant Women in Berlin, „Religion \& Gender” 3, 1: 76-89.

Jackson, Vivienne. 2013. 'This is Not the Holy Land': Gendered Filipino Migrants in Israel and the Intersectional Diversity of Religious Belonging, ,Religion \& Gender”, 3, 1: 6-21.

Jolly, Sussie i Reeves Hazel. 2005. GENDER and MIGRATION. Overview Report, Brighton: BRIDGE/Institute of Development Studies.

Jones-Correa, Michael. 1998. Different Paths: Gender, Immigration and Political Participation, „International Migration Review”, 32, 2: 326-349.

Kaźmierska, Kaja, Katarzyna Waniek i Andrzej Piotrowski. 2011. Biographical consequences of working abroad in the context of european mental space construction (draft version), 
Czego nie dowiemy się o globalnej rewolucji płci bez badania religii w życiu migrantów

referat wygłoszony na Euroidentities Final Conference, Bruksela, 9-10.02, www.euroidentities.org/Workinprogress/Filetoupload,248856,en.pdf [6.05.2016].

Kofman, Eleonore. 2000. Gender and International Migration in Europe, London: Routledge. Koralewska, Inga. 2016. Emancypacja religijna a percepcja roli kobiety w sytuacji migracyjnej na przyktadzie polskich migrantek w Islandii, ,Studia Humanistyczne AGH”, 3: 19-33.

Kordasiewicz, Anna. 2008. Stużaca, pracownik, domownik. Polki jako pomoce domowe w Neapolu w kontekście retradycjonalizacji instytucji, „Kultura i Społeczeństwo” 2: 79-109. Korolczuk, Elżbieta. 2014. 'The War on Gender'from a Transnational Perspective-Lessons for Feminist Strategising, w: Anti-Gender Movements on the Rise? Strategising for Gender Equality in Central and Eastern Europe, Berlin: Heinrich Böll Foundation, „Publication Series on Democracy", t. 38, https://pl.boell.org/sites/default/files/uploads/2014/10/ war_on_gender_korolczuk.pdf [6.05.2016].

Kościańska, Agnieszka. 2009. The „,power of silence”: Spirituality and women's agency beyond the Catholic Church in Poland, „Focaal - European Journal of Anthropology”, 53: 56-71.

Kronenberg, Anna. 2016. Migracje kobiet - strategie odzyskiwania głosu i ciała w twórczości literackiej Polek mieszkajacych w Wielkiej Brytanii i Irlandii, „Teksty Drugie”, 3: 98-115.

Kurien, Prema A. 2004. Christian by birth or rebirth? Generation and difference in an Indian American Christian church, w: Tony Carnes i Fenggang Yang (red.), Asian American Religions: Borders and Boundaries, New York University Press, 2004, s. 160-181.

Kuźma, Elżbieta. 2013. Migracje Polek z obszarów peryferyjnych kraju do metropolii europejskich. Analiza społecznych konsekwencji wspótczesnej mobilności przestrzennej kobiet na przykładzie Podlasianek w Brukseli, referat wygłoszony na konferencji „Młoda polska emigracja w UE jako przedmiot badań psychologicznych, socjologicznych i kulturowych”, Kraków, 23-24.09.2016, www.euroemigranci.pl/dokumenty/pokonferencyjna/Kuzma.pdf [6.04.2016].

Levitt, Peggy i Nadia Jaworsky. 2007. Transnational Migration Studies: Past Developments and Future Trends, „Annual Review of Sociology”, 33, 1: 129-156.

Levitt, Peggy. 1998. Social Remittances: Migration Driven, Local-Level Forms of Cultural Diffusion, „International Migration Review”, 32, 4: 926-948.

Levitt, Peggy. 2001. The Transnational Villagers, Berkeley: University of California Press.

Levitt, Peggy. 2003. 'You Know Abraham Was Really the First Immigrant': Religion and Transnational Migration', „International Migration Review”, 37, 3: 847-873.

Levitt, Peggy. 2008. Religion as a Path to Civic Engagement, „Ethnic and Racial Studies”, 31, 4: 766-791.

Lutz, Helma i Ewa Pallenga-Mollenbeck. 2012. „Łańcuchy opieki” w dyskursie $i$ w praktyce. Studium przypadku polskich i ukrainskich migrantek oraz ich rodzin, ,Recykling Idei”, 13: 77-88.

Mahler, Sarah J. i Patricia Pessar. 2001. Gendered Geographies of Power: Analyzing Gender Across Transnational Spaces, „Global Studies in Culture and Power”, 7, 4: 441-459.

Mahler, Sarah J. i Patricia Pessar. 2006. Gender Matters: Ethnographers Bring Gender from the Periphery toward the Core of Migration Studies, „International Migration Review”, 40, 1: 27-63. 
Małek, Agnieszka. 2008. Kościót i religia w doświadczeniach migracyjnych kobiet, w: Krystyna Slany (red.), Migracje kobiet. Perspektywa interdyscyplinarna, Kraków: Wydawnictwo Uniwersytetu Jagiellońskiego.

McDowell, Linda. 2007. Spaces of the home: absence, presence, new connections and new anxieties, „Home Cultures”, 4, 2: 129-146.

Morokvasic, Mirjana. 1984. Birds of Passage Are also Women, „International Migration Review", 18, 4: 886-907.

Muszel, Magdalena. 2013. Tradycyjna rola $w$ nietradycyjnej rodzinie. Transnarodowa migracja polskich żon i matek - studium przypadku, „Interalia”, 8: 91-103.

Parreñas, Rhacell Salazar. 2001. Servants of Globalization: Women, Migration, and Domestic Work, Stanford CA: Stanford University Press.

Peek, Lori. 2005. Becoming Muslim: the development of a religious identity, „Sociology of Religion", 66, 3: 215-242.

Phizacklea, Anne. 2003. Mirjana Morokvasic, Umut Erel i Kyoko Shinozaki (red.), Transnationalism, Gender and Global Workers, w: Crossing Borders and Shifting Boundaries, t. 1. Gender on the Move, Opladen Germany: Leske \& Budrich, s. 79-100.

Pustułka, Paula. 2015. Escaping workplace gender discrimination through mobility? Labormarket experiences of Polish female migrants in the West, „InterDisciplines”, 1, 59-94.

Radzik, Zuzanna. 2014. Najliczniejsza grupa, która uciekła z Kościoła na przestrzeni ostatnich 20 lat, sq kobiety. Z Zuzannq Radzik rozmawia Agata Diduszko-Zyglewska, w: Gender. Przewodnik Krytyki Politycznej, Warszawa: Wydawnictwo Krytyki Politycznej, s. 386-405.

Radzik, Zuzanna. 2015. Kościół kobiet, Warszawa: Wydawnictwo Krytyki Politycznej.

Rey, Jeanne. 2013. Mermaids and Spirit Spouses: Rituals as Technologies of Gender in Transnational African Pentecostal Spaces, „Religion \& Gender”, 3, 1: 60-75.

Ryan, Louise i Elena Vacchelli. 2012. Introduction: Gender, Religion and Migration, „Religion \& Gender", 3, 1: 1-5.

Sassen, Saskia. 2007. Globalizacja. Eseje o nowej mobilności ludzi i pieniędzy, Wydawnictwo Uniwersytetu Jagiellońskiego: Kraków.

Sherkat, Darren. 2000. 'That They Be Keepers of the Home': The Effect of Conservative Religion on Early and Late Transition into Housewifery, „Review of Religious Research”, 41, 3: 344-358.

Speck, Simon. 2013. 'Ulrich Beck's Reflecting Faith: Individualization, Religion and the Desecularization of Reflexive Modernity', „Sociology”, 47, 1: 157-172.

Szczepanikova, Alice. 2012. Becoming more conservative? Contrasting gender practices of two generations of Chechen women in Europe, „European Journal of Women's Studies”, 19, 4: 475-489.

Urbańska, Sylwia. 2015. Matka Polka na odległość. Z doświadczeń migracyjnych robotnic 1989-2010, Toruń: Wydawnictwo UMK.

Voicu, Malina. 2009. Religion and Gender across Europe, „Social Compass”, 56, 2: 144-162.

Wallerstein, Immanuel. 1992. The West, Capitalism, and the Modern World-System, „Review", 15, 4: 561-619.

Warner, Stephen i Judith Wittner (red.). 1998. Gatherings in Diaspora: Religious Communities and the New Immigration, Philadelphia: Temple University Press. 
Woodhead, Linda. 2013. Gender Differences in Religious Practice and Significance, „International Advances in Engineering and Technology", 13: 58-85.

Yang, Fenggang i Helen R. Ebaugh. 2001. Transformations in new immigrant religions and their global implications, „American Sociology Review” 66: 269-288.

\section{THE FORGOTTEN CONNECTION: RELIGION, WOMEN'S GLOBAL MIGRATION,} AND GENDER REVOLUTION

Since the late 1980s there has been a growing interest in women's migration, which led to the emergence of intersectional analysis as a main focus of gendered studies of mobility.

However, intersectional research of global migration processes rarely includes the analysis of religion in the experience of migrants, not asking about the possible role of religion in the gender revolution. Studies focus primarily (and often only) on the gendered division of care work, new forms of maintaining transnational families, and caring for children from abroad.

In this article I present a preliminary overview of studies, which analyze the intersection of migration, gender, care work, and religion. I show that the inclusion of religion in the analysis helps to answer in a more complex way, how the shifts in gender roles, contracts, and the public-private division happen.

Keywords: global migration, gender revolution, gender, religion and religiosity, transnationalism 